\title{
Giant Cell Reparative Granuloma in the Temporal Bone of a 4-Month-Old Infant
}

\author{
Yeonjoo Choi and Jong Woo Chung \\ Department of Otorhinolaryngology-Head and Neck Surgery, Asan Medical Center, \\ College of Medicine, University of Ulsan, Seoul, Korea
}

4 개월 영아의 측두골에 발생한 거대세포 육아종 1 예

최 연 주·정 종 우

울산대학교 의과대학 서울아산병원 이비인후과학교실

\author{
Received December 6, 2018 \\ Revised January 12, 2019 \\ Accepted January 15, 2019 \\ Address for correspondence \\ Jong Woo Chung, MD, PhD \\ Department of \\ Otorhinolaryngology- \\ Head and Neck Surgery, \\ Asan Medical Center, \\ College of Medicine, \\ University of Ulsan, \\ 88 Olympic-ro 43-gil, Songpa-gu, \\ Seoul 05505 , Korea \\ Tel $+82-2-3010-3718$ \\ Fax $+82-2-489-2773$ \\ E-mail jwchung@amc.seoul.kr
}

\begin{abstract}
Giant cell reparative granuloma $(\mathrm{GCRG})$ is a rare benign bone disease of unknown causes. Trauma is a suspected cause or contributor to the onset of GCRG, of which only a few cases have been reported worldwide. We report a case of temporal bone GCRG in a 4-month-old male newborn, who was born at full term via spontaneous vaginal delivery with recent presentation of right facial palsy. He had a right temporo-occipital craniectomy due to GCRG 1 month earlier. There had been no history of trauma. During the workup of the facial palsy complaint, we identified a lobulated mass in the right temporal bone by computed tomography and magnetic resonance imaging. The mass was mainly in the petrous portion of the temporal bone with extracranial extension through the occipital bone. This was consistent with a GCRG recurrence. The mass was removed via the transcrusal approach, and the final histopathology report confirmed it as recurrent GCRG.

Korean J Otorhinolaryngol-Head Neck Surg 2019;62(10):593-7
\end{abstract}

Key Words Bone neoplasms · Giant cell · Granuloma - Temporal bone.

\section{Introduction}

Giant cell reparative granuloma (GCRG) is a rare benign osteolytic lesion. Even though GCRG is a benign disease, it is locally aggressive and requires surgical excision. GCRGs must be distinguished from true giant cell tumors. Both show similar radiological findings, but true giant cell tumors are more likely to recur. ${ }^{1)}$ GCRGs commonly occur in the maxilla and mandible ${ }^{2,3)}$ as well as the short tubular bones of the hands and feet. However, GCRG occurred of the temporal bone is exceedingly rare, ${ }^{4-6)}$ with only a few cases ever having been reported worldwide. Because the cause of GCRG is un-

This is an Open Access article distributed under the terms of the Creative Commons Attribution Non-Commercial License (https://creativecommons.org/licenses/by-nc/4.0) which permits unrestricted non-commercial use, distribution, and reproduction in any medium, provided the original work is properly cited. known, it is helpful to consider mechanisms of onset on a case-by-case basis. However, some studies propose that the onset of GCRH may be related to the repairing process of bone tissue after traumatic bleeding or inflammation. ${ }^{7)}$ Here, we report a case of rapidly recurring GCRG of the temporal bone in a 4-month-old without any history of trauma. Approval of the Institutional Review Board in this study was exempted by IRB of Asan Medical Center.

\section{Case}

A 4-month-old male born at full term by spontaneous vaginal delivery presented with a recent right facial palsy. While there was no history of trauma, he had previously developed a mass of the right occipital area, which was identi- 
fied when he was 3 months old. The initial brain magnetic resonance imaging (MRI) findings demonstrated a well-circumscribed heterogeneously enhancing extradural mass with an internal necrotic portion in the right posterior fossa. There was a mass effect on the right cerebellar hemisphere, and the mass compressed the right sigmoid and transverse sinuses while causing bony remodeling of right temporal and occipital bones (Fig. 1). The mass was completely excised via a right temporo-occipital craniectomy. Histopathologic examination findings were consistent with GCRG. Postoperative brain MRI confirmed the total resection status of the right posterior fossa mass with few fluid collections and irregular thickening of the surgical cavity lining, suggesting postoperative changes (Fig. 2). One month after surgery, the right facial palsy appeared, and he was referred to our clinic for further evaluation and management.

On examination, the patient had right-side facial paralysis and a middle ear effusion. The facial palsy was rated HouseBrackmann grade III. Hearing in both ears was deemed to be normal after evaluation of the auditory brainstem response. Temporal bone MRI was performed to evaluate the causes of facial palsy.

Temporal bone MRI demonstrated $2.6 \times 2.6 \times 2.3 \mathrm{~cm}$ lobulated enhancing mass in the right temporal bone, mainly in petrous portion, with extracranial extension through the occipital bone, and abutting to the right facial nerve (Fig. 3). A focal area of increased enhancement was noted at the mastoid segment of the right facial nerve at the point abutting to the tumor, representing peritumoral inflammation. There was also a mass in the right temporo-occipital area, superior
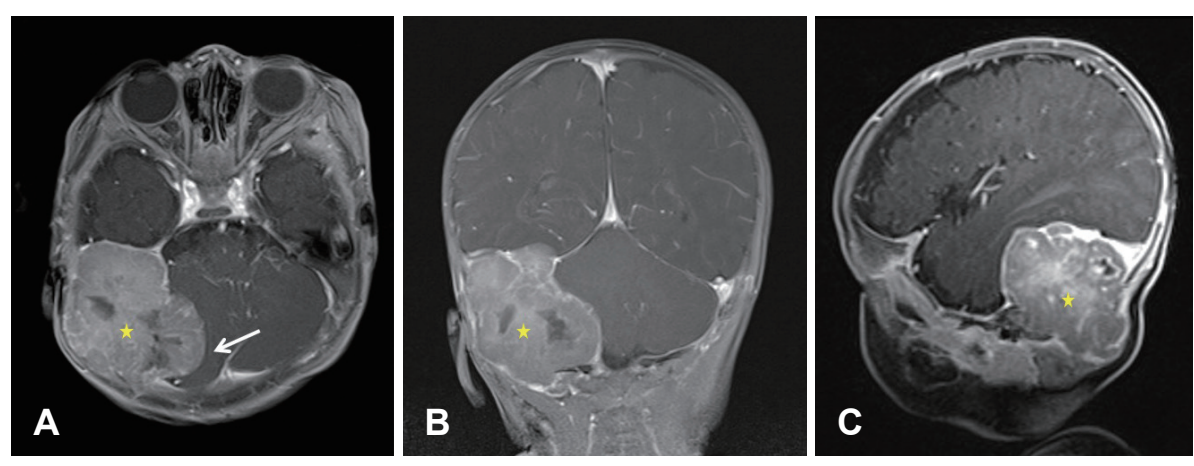

Fig. 1. Initial brain MR. A $5.5 \times 4.7 \times$ $4.0 \mathrm{~cm}$ well-circumscribed lobulated extra-dural mass (stars) having an internal necrotic portion in the right posterior fossa was compressing the right cerebellar hemisphere and right sigmoid and transverse sinuses (arrow), causing bony remodeling of right temporal and occipital bones. T1-Gd enhanced axial view (A). T1-Gd enhanced coronal view (B). T1-Gd enhanced sagittal view $(C)$.
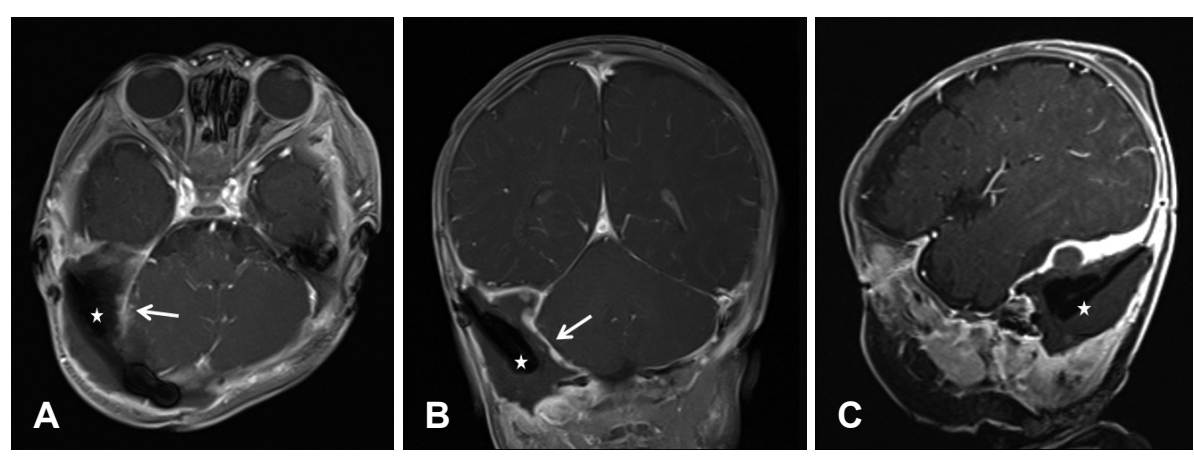

Fig. 2. Postoperative brain MR image after the first surgery. Grossly, the tumor after resection in the right posterior fossa. There was a fluid collection (stars) and irregular thickening with enhancement of the surgical cavity lining (arrows), probably representing postoperative changes in the surgical cavity. T1-Gd enhanced axial view (A). T1-Gd enhanced coronal view (B). T1-Gd enhanced sagittal view (C).
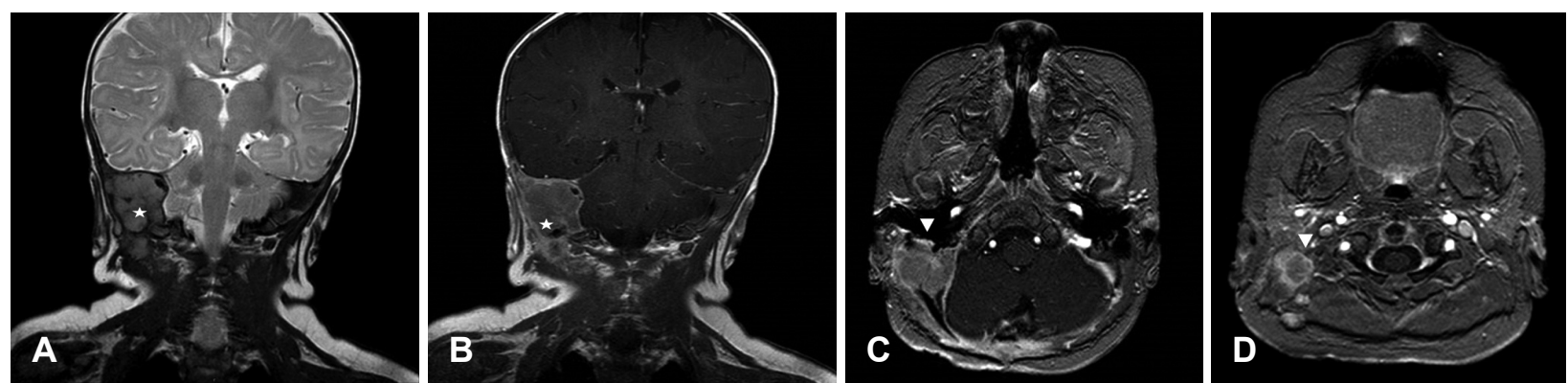

Fig. 3. Preoperative temporal bone MR images. The main mass (stars) located in the petrous portion with extracranial extension. T2 coronal view (A). T1-Gd enhanced coronal view (B). The main mass (arrowheads) abutting to the right facial nerve. T1 Fast Field Echo Gd-enhanced axial view (C and D). 

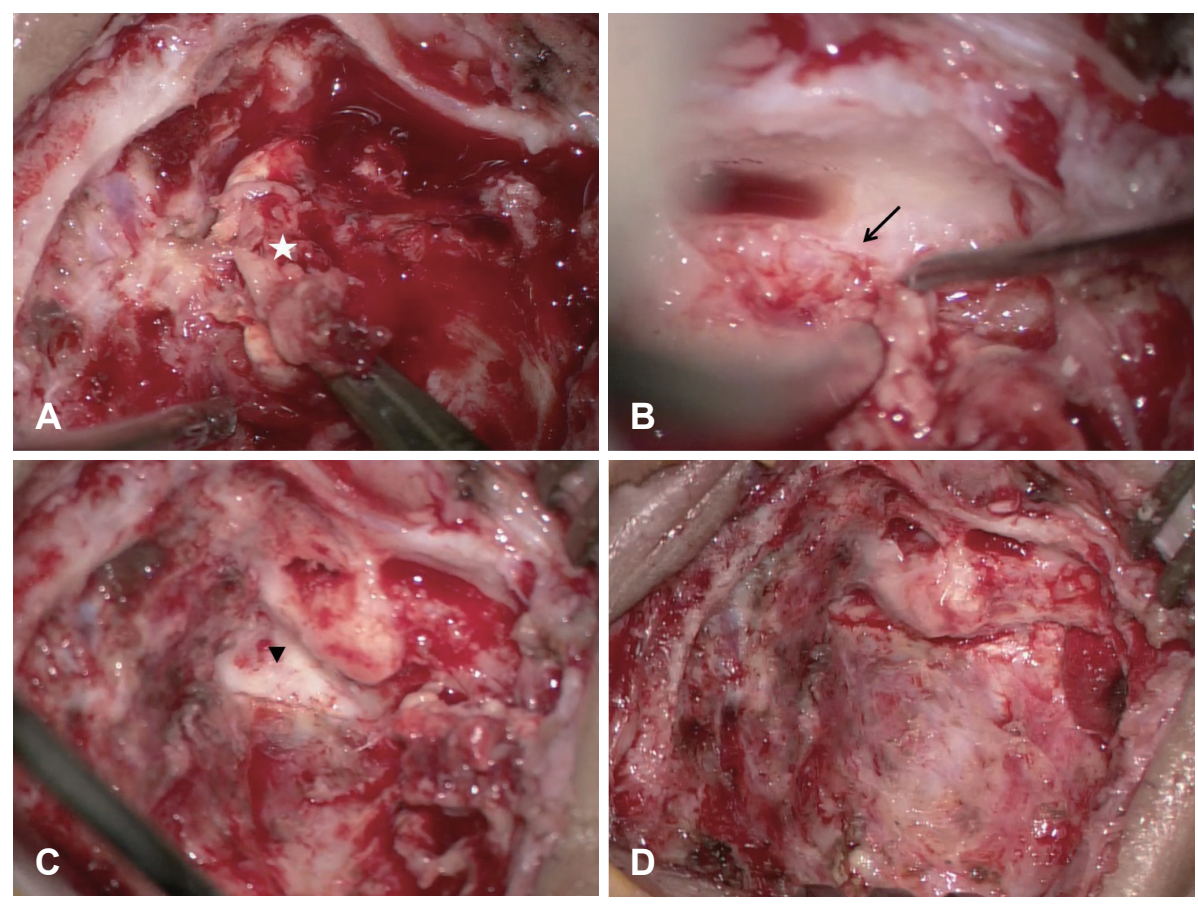

Fig. 4. Excision via the transcrusal approach to remove the tumor. The main mass (star, A). Excision of the mass from the facial nerve (arrow, B). The destruction of common crura of the superior and posterior semicircular canals (arrowhead, C). Total excision of the mass in the posterior fossa (D).

to the right transverse dural sinus.

The images suggested recurrent GCRG of the right temporal bone. High-dose corticosteroid therapy was initiated to manage the facial paralysis.

The recurrent mass was excised via the transcrusal approach. ${ }^{8)}$ After a postauricular incision and mastoidectomy, the mass was revealed to be extensively occupying the mastoid cavity and temporo-occipital, including surrounding inflammatory tissues. The mass was excised from the dura, and there were some adhesions (Fig. 4A). There was some new bone formation and granulation tissue, and all the bones and tissues were removed. The component attached to the facial nerve was released and separated, and the facial nerve was decompressed along its tympanic and mastoid segments (Fig. 4B). Posterior tympanotomy revealed that there was no middle ear involvement. No definite dural laceration was found. The tumor destroyed the common crura of the superior and posterior semicircular canals, while the lateral semicircular canal remained intact (Fig. 4C). A further incision was made superiorly to expose the mass in the posterior fossa and middle fossa area. The tumor extended into the dura and skull, and these extensions were also removed entirely (Fig. 4D). Harvested fat from the abdomen was used to obliterate the mastoid cavity.

The final histopathology report was consistent with a $3.5 \times$ $2.1 \times 1.8 \mathrm{~cm}$ GCRG in the right temporal area (Fig. 5). The mass was composed of a fibrillar connective tissue stroma

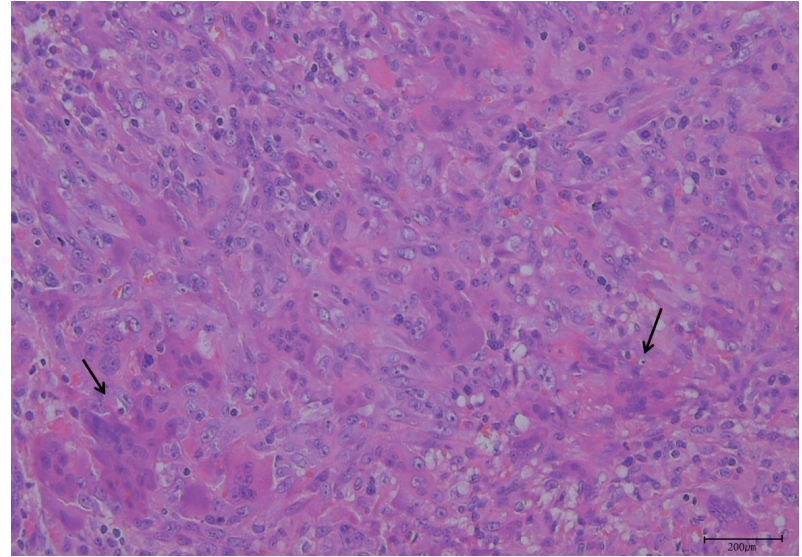

Fig. 5. Histologic features. Uneven clusters of multinuclear giant cells (arrows) are consistent with giant cell reparative granuloma.

and small, oval, and spindly mononuclear cells mixed with uneven clusters of multinuclear giant cells; there was also hemorrhage and fibrosis.

Six days after surgery, the patient was discharged without any acute complications. There was no apparent swelling of the temporal area.

Two months after the surgery, follow-up MRI scan was performed demonstrated complete removal of the mass.

Eight months after the surgery, facial expression improved to normal, and the threshold of the auditory brainstem response was $20 \mathrm{~dB}$. 


\section{Discussion}

Though the pathogenesis of GCRG remains controversial, a local reparative process in response to trauma-induced intraosseous hemorrhage is the most plausible explanation. ${ }^{7)}$ When bone gets injured, macrophages migrate into the damaged tissue to repair and generate a reparative granuloma." Since many patients with GCRGs have no history of trauma as same as in this case, other explanations are possible. Studies by Eisenbud et al. $^{2)}$ and Hirschl and Katz ${ }^{10)}$ suggested infectious and developmental causes of GCRGs. Maruno et al. ${ }^{11)}$ demonstrated that proliferation of the stromal component is part of the mechanism of GCRG development. Our patient had no clear trauma or infection history, other than the compression and strain involved in childbirth, which may have been extensive enough to hypothesize delivery as the traumatic event initiating GCRG development.

Because GCRGs have rarely been reported worldwide, they might be easily overlooked and misdiagnosed as other diseases. True giant cell bone tumors, aneurysmal bone cysts, chondroblastomas, and fibrous dysplasia are some of the differential diagnoses of GCRGs. As GCRGs are aggressive-despite being classified as benign lesions-distinguishing them from true giant cell tumors of bone is challenging. In the case of giant cell tumors, the disease affects older people $^{12)}$ and is rarely found in the skull. ${ }^{13)}$

Moreover, histologically, true giant cell tumors demonstrate larger (uniformly dispersed) giant cells and more nuclei than GCRGs. ${ }^{12)}$ Also, expression of p63 has been reported in true giant cell tumors, and this can be useful to distinguish these tumors from other non-neoplastic giant cell growths. ${ }^{14)}$ Distinguishing true giant cell tumors from GCRGs is essential because of the differences in prognosis and treatment regimens. Giant cell tumors have a worse prognosis than GCRGs; therefore, surgical excision plus adjuvant therapy, such as radiotherapy, is required for treatment. ${ }^{15)}$

The mean age of GCRG patients is under 20 years, while most patients with giant cell tumor are between 20 and 40 years old. ${ }^{9)}$ According to reports about GCRGs, age of onset varies from birth (congenital) to 72 years old. GCRGs are especially rare occurs children younger than 1 year, since the most plausible hypothesis of GCRG is trauma. However, a report about a congenital case suggests that birth trauma can be one of the causes of GCRG. ${ }^{16)}$ Even though the case we report does not have clear evidence of birth trauma, we highly presume the hypothesis of birth trauma considering his young age.

There are not lots of studies about genetic factors regarding GCRG. However one study introduces USP6 gene rearrangement occur preferentially in GCRG of the hands and feet to distinguish other morphologic mimics. ${ }^{17)}$ Even the genetic studies about GCRG in temporal bone are not thoroughly researched, we should bare in mind about possibility of genetic abnormalities and further studies about it are highly necessary.

A complete surgical excision is the treatment of choice for GCRGs. Adjuvant therapy is not needed if the complete excision is guaranteed. ${ }^{18,19)}$ If the mass cannot be removed entirely due to the involvement of adjacent complex structure, postoperative therapy should be seriously considered. ${ }^{9)}$

GCRGs have a good prognosis and a rare recurrence rate between $12 \%$ and $16 \%{ }^{12)}$ However, the prognosis and epidemiology of GCRGs occurring in temporal bone are not well established, because only a few cases have been documented. ${ }^{9)}$

In this case we report a recurrent temporal bone GCRG in an infant, demonstrating the course of the GCRG from diagnosis to treatment.

In conclusion, GCRGs of the temporal bone are difficult to diagnose because of their rarity. Our case of a recurrent GCRG of the temporal bone in an infant was successfully treated by excision via the transcrusal approach.

\section{ORCID}

Jong Woo Chung https://orcid.org/0000-0003-0765-9134

\section{REFERENCES}

1) Williams JC, Thorell WE, Treves JS, Fidler ME, Moore GF, Leibrock LG. Giant cell reparative granuloma of the petrous temporal bone: A case report and literature review. Skull Base Surg 2000;10(2):89-93.

2) Eisenbud L, Stern M, Rothberg M, Sachs SA. Central giant cell granuloma of the jaws: Experiences in the management of thirtyseven cases. J Oral Maxillofac Surg 1988;46(5):376-84.

3) Auclair PL, Cuenin P, Kratochvil FJ, Slater LJ, Ellis GL. A clinical and histomorphologic comparison of the central giant cell granuloma and the giant cell tumor. Oral Surg Oral Med Oral Pathol 1988;66(2):197-208.

4) Souter MA, Bird PA, Worthington JP. Giant cell reparative granuloma of the temporal bone treated with calcitonin. Otol Neurotol 2006;27(7):999-1002.

5) Kim HJ, Lee HK, Suh DC, Choi CG, Kim JK, Lee JH, et al. Giant cell reparative granuloma of the temporal bone: MR findings with pathologic correlation. AJNR Am J Neuroradiol 2003;24(6):1136-8.

6) Dimitrakopoulos I, Lazaridis N, Sakellariou P, Asimaki A. Giantcell granuloma in the temporal bone: A case report and review of the literature. J Oral Maxillofac Surg 2006;64(3):531-6.

7) Jaffe HL. Giant-cell reparative granuloma, traumatic bone cyst, and fibrous (fibro-oseous) dysplasia of the jawbones. Oral Surg Oral Med Oral Pathol 1953;6(1):159-75. 
8) Lee SM, Ko BJ, Sung HK, Kim HK, Hong JB, An YS. Hearing preservation with the transcrusal approach to the skull base lesion combined with other transcranial approach: Results of consecutive series of 5 cases. Korean J Otorhinolaryngol-Head Neck Surg 2017; 60(11):548-53.

9) Bernard F, Troude L, Bouvier C, Roche PH. "Giant cell reparative tumor: An exceptional differential diagnosis for a lytic lesion of the temporal bone." Neurochirurgie 2016;62(6):332-5.

10) Hirschl S, Katz A. Giant cell reparative granuloma outside the jaw bone. Diagnostic criteria and review of the literature with the first case described in the temporal bone. Hum Pathol 1974;5(2):171-81.

11) Maruno M, Yoshimine T, Kubo T, Hayakawa T. A case of giant cell reparative granuloma of the petrous bone: Demonstration of the proliferative component. Surg Neurol 1997;48(1):64-8.

12) Ciappetta P, Salvati M, Bernardi C, Raco A, Di Lorenzo N. Giant cell reparative granuloma of the skull base mimicking an intracranial tumor. Case report and review of the literature. Surg Neurol 1990;33(1):52-6.

13) Tesluk H, Senders CW, Dublin AB. Case report 562: Giant cell reparative granuloma of temporal bone. Skeletal Radiol 1989;18(8): 599-602.

14) Dickson BC, Li SQ, Wunder JS, Ferguson PC, Eslami B, Werier JA, et al. Giant cell tumor of bone express p63. Mod Pathol 2008;21 (4):369-75.

15) Bertoni F, Unni KK, Beabout JW, Ebersold MJ. Giant cell tumor of the skull. Cancer 1992;70(5):1124-32.

16) Wiles AB, Dilustro JF, Moody Antonio SA. Congenital giant cell granuloma of the temporal bone. Arch Otolaryngol Head Neck Surg 2011;137(9):942-6.

17) Agaram NP, LeLoarer FV, Zhang L, Hwang S, Athanasian EA, Hameed M, et al. USP6 gene rearrangements occur preferentially in giant cell reparative granulomas of the hands and feet but not in gnathic location. Hum Pathol 2014;45(6):1147-52.

18) Colclasure JB, Shea MC Jr, Graham SS. Giant cell lesions of the temporal bone. Am J Otol 1981;2(3):188-92.

19) Ung F, Li KK, Keith DA, McKenna MJ. Giant cell reparative granuloma of the temporal bone: Case report and review of the literature. Otolaryngol Head Neck Surg 1998;118(4):525-9. 